\title{
SEMEN CHARACTERISTICS, REPRODUCTIVE TRACT DEVELOPMENT, FEED EFFICIENCY AND SOME BLOOD PARAMETERS OF BALADI BULLS AND THEIR CROSSBREEDS WITH ABONDANCE AND TARENTAISE \\ Mohamed, M.Y.; A. M. Abd El-Hafeez; A. A. S. Mahgoub and S. M. Zahed. \\ Animal Production Research Institute, Agricultural Research Center, Ministry of Agriculture, Egypt.
}

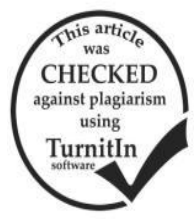

\begin{abstract}
Twenty four Bovine males representing three genotypes: Pure local "Baladi" (B), 1/4 Baladi 3/4 Abondance (BA×A) and 1/4 Baladi 3/4 Tarentaise (BT×T). Eight males in each genotype were subjected to evaluate their semen characteristics, reproductive tract development, growth rate, feed efficiency, some blood parameters, thermo-regulatory parameters and body dimensions at puberty and sexual maturity. BT $\times \mathrm{T}$ bulls showed the best feed efficiency compared with those of BA $\times$ A and B bulls. Serum total protein, albumin, globulin, glucose, cholesterol, $\mathrm{T}_{3}$ and testosterone in BT $\times \mathrm{T}$ had the highest values, followed by $\mathrm{BA} \times \mathrm{A}$, while $\mathrm{B}$ bulls had the lowest ones, either at puberty or sexual maturity. Total weight gain and daily weight gain were significantly higher in $\mathrm{BT} \times \mathrm{T}$ compared to $\mathrm{BA} \times \mathrm{A}$ and $\mathrm{B}$ bulls. Thermo-regulatory parameters and body dimensions were affected by the different genotypes. Crossbreeds bulls $(\mathrm{BT} \times \mathrm{T}$ and $\mathrm{BA} \times \mathrm{A})$ reached age of puberty, sexual maturity and slaughter weight (60 days post sexual maturity) earlier than Baladi bulls. Semen characteristics among the three genotypes were highly significant $(\mathrm{P}<0.0001)$ especially of BT $\times \mathrm{T}$ followed by BA $\times \mathrm{A}$ compared to B bulls. Testes parameters of BT $\times \mathrm{T}$ bulls had the highest values for all studied parameters, followed by BAXA, while those of B were the lowest. Sperm production per gram of testicular tissue was also significantly higher in BT $\times$ T bulls than the other two genotypes. This study indicated that the superiority of crossbreed bulls especially; BT $\times \mathrm{T}$ in growth, reproductive performance and feed efficiency compared with pure Baladi bulls.
\end{abstract}

Keywords: Genotypes, semen, reproductive tract, feed efficiency, puberty and maturity.

\section{INTRODUCTION}

Reproductive performance of bulls is a complex trait because of several physiological processes such as the development of reproductive system from birth to puberty, spermatogenesis, ejaculation and mating behavior, which involves libido and copulation. For optimum semen quality, all these physiological processes should be coordinated. Spermatogenic activity of animals is a genetically controlled process and might be affected by many factors including breed or genotype, body weight, age and nutritional status (AbdEl-Hakeam et al., 1994).

Quantification of the sperm production capacity in breeding animals allows for assessment of the efficiency of spermatogenesis in males kept under different environmental conditions and enhances critical evaluation of season effect, breed, age, bioclimatic factors, hormones, chemicals and drugs (Amann, 1981). Reproductive success is essential for calves' producers to be profitable (Hansen, 2006).

Crossbreeding between two breeds is well recognized as a method for improving productivity of animals (Dahman et al., 1985).

All factors related to testicular degeneration, including hereditary and pathological conditions should be carefully considered as they may seriously affect semen quality via testicular development. Hoogenboezem and Swanepoel (2000) reported that testicular degeneration might be due to exposure to heat stress, nutritional deficiencies and management-related factors such as fat deposition in the scrotum and poor body condition.

Studying the reproductive tract development and the epididymal sperm reserves in different genotypes, age and feed efficiency might provide some information on the factors which may play a significant role in improving the reproductive efficiency of males and subsequently improving breeding programs (Murray et al., 1990).

Therefore, this work was conducted to study reproductive performance of some genotype bulls through its weight of reproductive organs, semen characteristics, epididymal sperm reserves as affected by feed efficiency, thermo-regulatory parameters and body dimensions.

\section{MATERIALS AND METHODS}

The present study was carried out at Sids Experimental Station, located at Bani Suef governorate in middle Egypt, belonging to Animal Production Research Institute (APRI), Agricultural Research Center, Ministry of Agriculture.

Twenty four Bovine males representing three genotypes: Pure local "Baladi" (B), 1/4 Baladi 3/4 Abondance $(\mathrm{BA} \times \mathrm{A})$ and1/4 Baladi 3/4 Tarentaise $(\mathrm{BT} \times \mathrm{T})$. Eight males in each genotype were subjected in this study. The experiment started at puberty age of animals (Abd El-Hafeez et al., 2015). All males were healthy, showing no symptoms of malnutrition or any disease.

\section{Management and feeding:}

Males were housed under open sheds belonging to Sids Experimental Station and individually fed to cover their requirements of dry matter (DM), crude protein (CP) and total digestible nutrients (TDN) according to NRC (1988). Feeding allowances were monthly adjusted according to changes in body weight until they were slaughtered.

The experimental ration was formulated to contain $40 \%$ concentrate feed mixture (CFM), $30 \%$ berseem hay (BH) and 30\% rice straw (RS). Whereas CFM was offered twice daily (at 8 am and $4 \mathrm{pm}$ ), berseem hay and rice straw were given twice daily (at 9 am and 5 pm). Fresh 
and clean drinking water was available at all times. Body weight of males was recorded monthly before morning feeding. Daily gain, average feed intake and feed efficiency were determined. Also, thermal regulatory parameters and body dimensions were monthly measured. Semen collection and evaluation

Semen ejaculates were collected starting from puberty and continued till sexual maturity to evaluate their semen production. Semen was collected between 8.00 and 10.00 am using an artificial vagina. Each male was sexually stimulated by allowing two false mounts and 2-3 min. restraint before collection. Two successive ejaculates were collected biweekly from each male in an interval of one hour. Ejaculate volume was recorded using graduated collecting tube. Sperm motility and $\mathrm{pH}$ of the freshly collected semen were immediately recorded after collection using a microscope with warmer stage and $\mathrm{pH}$ meter. Number of spermatozoa $/ \mathrm{ml}$ was counted using hemocytometer. Total and motile sperm output/ejaculate were calculated.

Bulls were considered sexually mature when produced two successive ejaculates containing one billion sperm /ml (Hafez, 1987). Age, body weight and testes circumference at sexual maturity were also recorded.

Three animals were slaughtered after 60 days of sexual maturity. Live body weight and testes circumference (TC) before slaughter were recorded for each animal. After slaughtering, the genital tract was removed and trimmed from fat, then separated to its organs. Testes and epididymis $(\mathrm{T}+\mathrm{E})$ including tunica vaginalis were weighted to the nearest gram. After removal of tunica vaginalis and separation of epididymis from testes, weights were separately recorded for each part (cauda, corpus and caput).

Accessory sex glands weights (ampulla, seminal vesicles and Cowper's glands), penis weight and penis length were also recorded. Total epididymal sperm reserves and its distribution in cauda, corpus and caput were measured by direct count technique as described by AbdEl-Hakeam et al. (1978). Sperm cells were counted using the hemocytometer.

Blood samples and serum analysis:

Blood samples of animals were individually collected from the jugular vein in the morning before excess to drinking and feeding at the beginning of the experiment and monthly until the sexual maturity. The collected blood samples were centrifuged at 3000 r.p.m. for 15 minutes and the obtained clear samples serum were stored at $-20^{\circ} \mathrm{C}$ until analysis. Concentrations of total protein and albumin were estimated in serum using kits of Diamond Diagnostic, EC Hannover, Germany. Globulin level was calculated by the difference between total protein and albumin. Glucose and cholesterol were quantified in serum by using kits of Spinreact, S.A.U. Ctra. Santa Coloma, 7 E-17176 Sant Esteve de Bas (GI) Spain by means of spectrophotometer. Direct radioimmunoassay (RIA) technique was performed for assessment of total serum tri-iodothyronine $\left(\mathrm{T}_{3}\right)$ concentrations. Ready antibody-coated tube kits (Total $\mathrm{T}_{3}$ RIA KIT. REF IM 1699-2013-08-14-IM3287) was used according to the procedure outlined by the manufacturer. Assessment of total testosterone concentration was performed according to the method of Jaffe and Behman (1974) using Coat-A-count I125 radioimmunoassay (RIA) kits purchased from diagnostic products Corporation, Loss Angeles, California, 90045 USA by the manufactures information, the antiserum is highly specific for testosterone. The cross activity was $20 \%$ with 4-Estern-17-01-3-one, $16 \%$ with 11-ketotestosterone, $3.3 \%$ with 5-dihydro testosterone, $1.7 \%$ with Methyl test, 1.2 with 11-B-Hydroxtestosterone and less than $1 \%$ with other steroids.

\section{Statistical analyses:}

All collected data were statistically analyzed using the general linear model procedure (SAS, 2002). The differences among means were tested using Duncan's Multiple-rang test (Duncan, 1955). The model in statistical analysis was:

$$
\begin{aligned}
& \text { Where: } \quad \mathbf{Y}_{\mathrm{ij}}=\boldsymbol{\mu}+\mathbf{G}_{\mathbf{i}}+\mathbf{e}_{\mathbf{i j}} \\
& \mathrm{Y}_{\mathrm{ij}}=\text { an observation } \\
& \mu=\text { overall means } \\
& \mathrm{G}_{\mathrm{i}}=\text { effect of genotype }(\mathrm{i}=\mathrm{B}, \mathrm{BA} \times \mathrm{A}, \mathrm{BT} \times \mathrm{T}) \\
& \mathrm{e}_{\mathrm{ij}}=\text { random error }
\end{aligned}
$$

\section{RESULTS AND DISCUSSION}

\section{$A$ - Growth performance, feed intake and feed efficiency:}

Data of Table 1 indicated that the total weight gain and daily weight gain of bulls were significantly affected by genotype. It was clear from the present results that total gain and daily gain were significantly higher in $\mathrm{BT} \times \mathrm{T}$ compared to $\mathrm{BA} \times \mathrm{A}$ and $\mathrm{B}$ bulls. The difference between $\mathrm{BA} \times \mathrm{A}$ and $\mathrm{B}$ bulls was not significant. These results may be related to the levels of total protein (TP), albumin (Alb), globulin (Glob), glucose $(\mathrm{Glu})$ and tri-iodothyronine $\left(\mathrm{T}_{3}\right)$ concerning $\mathrm{BT} \times \mathrm{T}$, which recorded the highest values followed by $\mathrm{BA} \times \mathrm{A}$; while $\mathrm{B}$ bulls recorded the lowest values (Table 2). These results are in agreement with Abd El-Hafeez et al. (2015), they reported that total and daily weight gain were significantly higher in $\mathrm{BT} \times \mathrm{T}$ than those in growing Baladi calves.

Comparisons among genotypes indicated that total DM, TDN and $\mathrm{CP}$ intakes in $\mathrm{BT} \times \mathrm{T}$ and $\mathrm{BA} \times \mathrm{A}$ were significantly higher than that in B bulls (Table 1). These results are in agreement with Abd El-Hafeez et al. (2015) who indicated that total DM and TDN intakes were significantly higher in male of $\mathrm{BT} \times \mathrm{T}$ compared to B calves. However, Ibrahim et al. (2005) indicated that Baladi and its crosses with Abondance and Tarentaise did not differ in the daily feed intake under the middle Egypt conditions.

Feed efficiency expressed as $\mathrm{kg}$ of DMI, TDN and $\mathrm{CP}$ required to producing one $\mathrm{kg}$ gain is presented in Table 1. It was observed that BT $\times \mathrm{T}$ bulls had the best feed efficiency as DM, TDN and CP compared with those of BA $\times$ A and B bulls. This result might be due to the higher daily gain for this group. The same trend was obtained by Ibrahim et al. (2005). They reported that grading-up of Baladi with Abondance and Tarentaise resulted in an increase in feed consumption per $\mathrm{kg}$ gain. 
Table 1: Growth performance, feed intake and feed efficiency of Baladi bulls and their crossbreds with Abondance and Tarentaise.

\begin{tabular}{|l|c|c|c|c|c|}
\hline \multirow{2}{*}{ Traits } & \multicolumn{3}{|c|}{ Genotype } & \multirow{2}{*}{ SSE } & \multirow{2}{*}{ P. value } \\
\cline { 2 - 4 } & B. & BA $\times \mathbf{A}$ & BT $\times \mathbf{T}$ & & \\
\hline Initial weight at puberty, kg & $244.33^{\mathrm{c}}$ & $255.67^{\mathrm{b}}$ & $263.67^{\mathrm{a}}$ & 1.342 & 0.0001 \\
\hline Final weight at slaughter, kg & $424.67^{\mathrm{c}}$ & $437.33^{\mathrm{b}}$ & $459.50^{\mathrm{a}}$ & 3.685 & 0.0001 \\
\hline Total gain, kg & $180.34^{\mathrm{b}}$ & $181.66^{\mathrm{b}}$ & $195.83^{\mathrm{a}}$ & 4.192 & 0.03 \\
\hline Daily gain, g & $663.43^{\mathrm{b}}$ & $708.23^{\mathrm{b}}$ & $794.44^{\mathrm{a}}$ & 20.104 & 0.0009 \\
\hline Average daily feed intake/head: & & & & & \\
\hline DM, kg & $8.26^{\mathrm{b}}$ & $8.88^{\mathrm{a}}$ & $9.05^{\mathrm{a}}$ & 0.094 & 0.0002 \\
\hline TDN intake, kg & $4.42^{\mathrm{b}}$ & $4.76^{\mathrm{a}}$ & $4.84^{\mathrm{a}}$ & 0.043 & 0.0001 \\
\hline CP, g & $829.80^{\mathrm{b}}$ & $901.20^{\mathrm{a}}$ & $904.00^{\mathrm{a}}$ & 5.437 & 0.0001 \\
\hline Feed efficiency: & & & & & \\
\hline DM/ gain, $\mathrm{kg} / \mathrm{kg}$ & $12.45^{\mathrm{a}}$ & $12.54^{\mathrm{a}}$ & $11.39^{\mathrm{b}}$ & 0.218 & 0.0001 \\
\hline TDN/gain, $\mathrm{kg} / \mathrm{kg}$ & $6.66^{\mathrm{a}}$ & $6.72^{\mathrm{a}}$ & $6.09^{\mathrm{b}}$ & 0.152 & 0.0001 \\
\hline CP/ gain, g/g & $1.25^{\mathrm{a}}$ & $1.27^{\mathrm{a}}$ & $1.14^{\mathrm{b}}$ & 0.035 & 0.0001 \\
\hline
\end{tabular}

a,b and : Means within each row with different superscripts are significantly differ $(\mathbf{P}<0.05)$.

\section{$B$ - Blood parameters:}

Blood parameters are important index of physiological, pathological and nutritional status of the organism. Changes in blood parameters when compared to the normal values could be used to interpret the metabolic status of the animal and perhaps nutrient adequacy of feed consumed (Nworgu et al., 2007). Data presented in Table 2 showed that TP, Alb and Glob in $\mathrm{BT} \times \mathrm{T}$ had the highest values, followed by $\mathrm{BA} \times \mathrm{A}$, while $\mathrm{B}$ bulls had the lowest ones, either at puberty or sexual maturity. This superiority in $\mathrm{BT} \times \mathrm{T}$ and $\mathrm{BA} \times \mathrm{A}$ compared to $\mathrm{B}$ bulls may be due to the higher feed intake (Table 1), metabolic rate and enzymes activity, which was reflected on the blood metabolites (Table 2). The same trend was obtained by Abd El-Hafeez et al. (2015) who found that serum TP, Alb and Glob in $\mathrm{BT} \times \mathrm{T}$ recorded the highest values, followed by $\mathrm{BA} \times \mathrm{A}$, while $\mathrm{B}$ bulls recorded the lowest ones. In addition, Ashmawy et al. (2002) indicated that plasma TP level was higher in Friesian crossbred than B bulls.

Table 2: Some blood parameters at puberty and sexual maturity of Baladi bulls and their crossbreds with Abondance and Tarentaise.

\begin{tabular}{|c|c|c|c|c|c|}
\hline \multirow{2}{*}{ Traits } & \multicolumn{3}{|c|}{ Genotype } & \multirow{2}{*}{$\pm \mathrm{SE}$} & \multirow{2}{*}{ P. value } \\
\hline & B. & $\mathbf{B A} \times \mathbf{A}$ & BT $\times$ T & & \\
\hline & \multicolumn{4}{|c|}{ At puberty } & \\
\hline Total protein $(\mathrm{g} / \mathrm{dl})$ & $6.32^{\mathrm{c}}$ & $6.89^{\mathrm{b}}$ & $7.35^{\mathrm{a}}$ & 0.101 & 0.0001 \\
\hline Albumin $(\mathrm{g} / \mathrm{dl})$ & $4.19^{b}$ & $4.39^{\mathrm{ab}}$ & $4.59^{\mathrm{a}}$ & 0.106 & 0.0001 \\
\hline Globulin (g/dl) & $2.13^{\mathrm{b}}$ & $2.50^{\mathrm{ab}}$ & $2.76^{\mathrm{a}}$ & 0.151 & 0.0001 \\
\hline $\mathrm{A} / \mathrm{G}$ ratio & $1.97^{\mathrm{a}}$ & $1.76^{\mathrm{a}}$ & $1.66^{\mathrm{a}}$ & 0.161 & 0.0001 \\
\hline Glucose $(\mathrm{mg} / \mathrm{dl})$ & $67.03^{\mathrm{c}}$ & $79.34^{b}$ & $98.61^{\mathrm{a}}$ & 2.509 & 0.0001 \\
\hline Cholesterol (mg/dl) & $122.31^{b}$ & $157.14^{\mathrm{a}}$ & $171.15^{\mathrm{a}}$ & 6.168 & 0.0002 \\
\hline $\mathrm{T}_{3}(\mathrm{nmol} / \mathrm{L})$ & $2.28^{\mathrm{c}}$ & $2.82^{\mathrm{b}}$ & $3.33^{\mathrm{a}}$ & 0.089 & 0.0001 \\
\hline \multirow[t]{2}{*}{ Testosterone level (ng/ml) } & $0.803^{\mathrm{c}}$ & $0.893^{\mathrm{b}}$ & $0.993^{\mathrm{a}}$ & 0.021 & 0.0001 \\
\hline & \multicolumn{4}{|c|}{ At sexual maturity } & \\
\hline Total protein $(\mathrm{g} / \mathrm{dl})$ & $6.88^{\mathrm{c}}$ & $7.40^{\mathrm{b}}$ & $7.70^{\mathrm{a}}$ & 0.070 & 0.0001 \\
\hline Albumin $(\mathrm{g} / \mathrm{dl})$ & $4.51^{\mathrm{b}}$ & $4.67^{\mathrm{ab}}$ & $4.79^{\mathrm{a}}$ & 0.050 & 0.0001 \\
\hline Globulin (g/dl) & $2.37^{\mathrm{b}}$ & $2.71^{\mathrm{ab}}$ & $2.91^{\mathrm{a}}$ & 0.089 & 0.0001 \\
\hline A/G ratio & $1.90^{\mathrm{a}}$ & $1.73^{\mathrm{ab}}$ & $1.65^{\mathrm{b}}$ & 0.081 & 0.0001 \\
\hline Glucose $(\mathrm{mg} / \mathrm{dl})$ & $75.48^{\mathrm{c}}$ & $90.27^{b}$ & $113.79^{\mathrm{a}}$ & 4.311 & 0.0001 \\
\hline Cholesterol (mg/dl) & $139.78^{\mathrm{c}}$ & $170.39^{b}$ & $188.40^{\mathrm{a}}$ & 5.625 & 0.001 \\
\hline $\mathrm{T}_{3}(\mathrm{nmol} / \mathrm{L})$ & $2.87^{\mathrm{c}}$ & $3.71^{\mathrm{b}}$ & $4.31^{\mathrm{a}}$ & 0.171 & 0.0001 \\
\hline Testosterone level (ng/ml) & $1.08^{\mathrm{c}}$ & $1.40^{\mathrm{b}}$ & $1.68^{\mathrm{a}}$ & 0.087 & 0.0001 \\
\hline
\end{tabular}

a,b and : Means within each row with different superscripts are significantly differ $(\mathbf{P}<0.05)$.

Serum glucose (Glu) values (Table 2) followed the same trend as that of TP, Alb and Glob, either at puberty or sexual maturity. This superiority of $\mathrm{BT} \times \mathrm{T}$ and $\mathrm{BA} \times \mathrm{A}$ compared to $\mathrm{B}$ bulls may be due to the increasing of feed intake as DM and TDN (Table1). The same finding was reported by Ashmawy et al. (2002) who found that plasma Glu level was higher in crossbred than B calves. Also, Ibrahim et al. (2005) reported that serum Glu levels were 52.36, 92.13 and $75.19 \mathrm{mg} / \mathrm{dl}$ for B, AxB and BxT bulls, respectively.
The results in Table 2 indicated that serum cholesterol values were significantly higher $(\mathrm{P}<0.001)$ in $\mathrm{BT} \times \mathrm{T}$ and $\mathrm{BA} \times \mathrm{A}$ compared with B bulls at puberty. At sexual maturity, the values were significantly higher $(\mathrm{P}<0.001)$ in $\mathrm{BT} \times \mathrm{T}$ followed by $\mathrm{BA} \times \mathrm{A}$, while those of $\mathrm{B}$ were the lowest. This result may be attributed to the increases in voluntary feed intake (Table 1), rumen fermentation, enzymes activities and high thyroid gland secretion (Table 2). Abd El-Hafeez et al. (2015) reported that serum cholesterol level was significantly 
higher in $\mathrm{BT} \times \mathrm{T}$ followed by $\mathrm{BA} \times \mathrm{A}$ compared with $\mathrm{B}$ bulls. On the other hand, Abd El-Hafeez et al. (2014) found that serum cholesterol concentration was 153.33, 172.67 and $193.33 \mathrm{mg} / \mathrm{dl}$ for B, BT $\times \mathrm{T}$ and $\mathrm{BA} \times \mathrm{A}$ cows, respectively.

Mean values of $T_{3}$ of the three different genotypes studied are shown in Table 2. The data indicated that $T_{3}$ concentration were significantly higher $(\mathrm{P}<0.0001)$ in $\mathrm{BT} \times \mathrm{T}$ than $\mathrm{BA} \times \mathrm{A}$ followed by $\mathrm{B}$ bulls, either at puberty or sexual maturity. $T_{3}$ value is proportionally correlated with the live body weight being low in lighter bulls (Baladi) and high in heavier bulls (crossbreeds) as indicated in Tables 1 and 2 . Collier et al. (1984) reported that the pituitary thyroid axis is an important physiological factor controlling metabolic processes. Thyroid hormones synergize with other hormones to promote growth (Lapierre et al., 1990).

The present results showed that $\mathrm{BT} \times \mathrm{T}$ crossbreed bulls had the highest values of $\mathrm{T}_{3}(3.33$ and $4.31 \mathrm{nmol} /$ L), but Baladi bulls had the lowest values (2.28 and $2.87 \mathrm{nmol} / \mathrm{L}$ ) at puberty and sexual maturity, respectively. These results were in harmony with Abd El-Hafeez et al. (2014) who found that $\mathrm{T}_{3}$ and $\mathrm{T}_{4}$ values of lighter cows (B) were significantly lower than those of heavier cows $(\mathrm{BT} \times \mathrm{T}$ and $\mathrm{BA} \times \mathrm{A})$.

Levels of testosterone of different genotype groups at puberty and sexual maturity are shown in Table 2. It was observed that testosterone level was significantly higher $(\mathrm{P}<0.0001)$ in $\mathrm{BT} \times \mathrm{T}$ and $\mathrm{BA} \times \mathrm{A}$ than $B$ bulls, either at puberty or sexual maturity, where $\mathrm{BT} \times \mathrm{T}$ group recorded the highest concentration followed by $\mathrm{BA} \times \mathrm{A}$, while $\mathrm{B}$ group recorded the lowest ones. The obtained data showed a gradual increase in testosterone concentration with advancing of age and weight. Such rise was due to the continuous development of testicular tissue as a result of age and weight progress toward puberty and sexual maturity. The present results are in agreement with Mokhless and Ibrahim (1990). They reported that there were increases in blood testosterone with advancing of age. Abd ElMoty et al. (2001) also found highly significant positive correlation coefficients among body weight, testes circumference and testosterone levels in both Buffalo and Friesian bulls. In addition, Sajjad et al. (2007) reported that the levels of blood serum testosterone were correlated with scrotal circumference and semen volume.

Generally, the obtained results of blood parameters studied indicated normal physiological and healthy status of all experimental bulls.

\section{$B$ - Thermo-regulatory parameters:}

The average values of skin temperature (ST), rectal temperature $(\mathrm{RT})$, respiration rate $(\mathrm{RR})$ and pulse rate $(\mathrm{PR})$ of $\mathrm{B}$ and their crossbreds $\mathrm{BA} \times \mathrm{A}$ and $\mathrm{BT} \times \mathrm{T}$ bulls at puberty and sexual maturity are presented in Table 3. The present data indicated that ST and RT significantly increased $(\mathrm{P}<0.04)$ with $\mathrm{BA} \times \mathrm{A}$ and insignificantly increased with $\mathrm{BT} \times \mathrm{T}$ compared to $\mathrm{B}$ bulls at puberty, while, ST was significantly increased $(\mathrm{P}<0.0001)$ in both $\mathrm{BA} \times \mathrm{A}$ and $\mathrm{BT} \times \mathrm{T}$ compared to $\mathrm{B}$ bulls at sexual maturity. However, RT was not significantly different between $\mathrm{BT} \times \mathrm{T}$ and $\mathrm{B}$ bulls at sexual maturity. The diurnal change in rectal temperature was more pronounced in crossbreds than B bulls. This pattern of response could be attributed to the fact that $\mathrm{B}$ bulls were relatively more heat tolerant than crossbreds $(\mathrm{BA} \times \mathrm{A}$ and $\mathrm{BT} \times \mathrm{T})$ bulls. This result is in agreement with that of Abd El-Hafeez et al. (2015) who indicated that ST insignificantly increased in $\mathrm{BA} \times \mathrm{A}$ and $\mathrm{BT} \times \mathrm{T}$ compared to $\mathrm{B}$ bulls, while $\mathrm{RT}$ significantly increased in $\mathrm{BA} \times \mathrm{A}$ and insignificantly increased with $\mathrm{BT} \times \mathrm{T}$ compared to B bulls. Also, Ashmawy et al. (2002) found that body temperature was significantly increased in Friesian crossbreed compared to Baladi calves. At puberty, the mean value of $R R$ was significantly increased $(\mathrm{P}<0.0001)$ by 4 and 2 breath/min for $\mathrm{BA} \times \mathrm{A}$ and $\mathrm{BT} \times \mathrm{T}$ than $\mathrm{B}$ bulls, respectively, the same trend was obtained at sexual maturity that may explain the greater rise in $R R$ in crossbreeds, which depends on respiratory evaporative cooling mechanism to dissipate heat load for maintaining homoeothermic. This result is in harmony with Ashmawy et al. (2002) who reported that RR significantly higher in Friesian crossbreed than Baladi calves. It is of interest to note that present data of PR among the different experimental genotypes (Table 3) followed the same trend as that of RR in males, either at puberty or sexual maturity. This result may confirm the positive relation between RR and PR.

Table 3: Thermo-regulatory parameters of Baladi bulls and their crossbreds with Abondance and Tarentaise at puberty and sexual maturity.

\begin{tabular}{|c|c|c|c|c|c|}
\hline \multirow{2}{*}{ Traits } & \multicolumn{3}{|c|}{ Genotype } & \multirow{2}{*}{$\pm \mathrm{SE}$} & \multirow{2}{*}{ P. value } \\
\hline & B. & $\mathbf{B A} \times \mathbf{A}$ & BT $\times \mathbf{T}$ & & \\
\hline & \multicolumn{4}{|c|}{ At puberty } & \\
\hline Skin temperature $\left({ }^{\circ} \mathrm{C}\right)$ & $38.70^{\mathrm{b}}$ & $39.07^{\mathrm{a}}$ & $38.97^{\mathrm{ab}}$ & 0.098 & 0.04 \\
\hline Rectal temperature $\left({ }^{\circ} \mathrm{C}\right)$ & $37.65^{b}$ & $38.40^{\mathrm{a}}$ & $38.3^{\mathrm{a}}$ & 0.114 & 0.001 \\
\hline Respiration rate, (breath/min.) & $33.83^{\mathrm{c}}$ & $37.83^{\mathrm{a}}$ & $35.83^{\mathrm{b}}$ & 0.342 & 0.0001 \\
\hline \multirow[t]{2}{*}{ Pulse rate (pulse/min.) } & $32.17^{\mathrm{b}}$ & $35.33^{\mathrm{a}}$ & $34.67^{\mathrm{a}}$ & 0.325 & 0.0001 \\
\hline & \multicolumn{4}{|c|}{ At sexual maturity } & \\
\hline Skin temperature $\left({ }^{\circ} \mathrm{C}\right)$ & $38.20^{\mathrm{b}}$ & $39.13^{\mathrm{a}}$ & $38.88^{\mathrm{a}}$ & 0.101 & 0.0001 \\
\hline Rectal temperature $\left({ }^{\circ} \mathrm{C}\right)$ & $37.80^{\mathrm{b}}$ & $38.50^{\mathrm{a}}$ & $38.08^{\mathrm{b}}$ & 0.110 & 0.001 \\
\hline Respiration rate, (breath/min.) & $28.50^{\mathrm{c}}$ & $32.17^{\mathrm{a}}$ & $29.67^{b}$ & 0.292 & 0.0001 \\
\hline Pulse rate (pulse/min.) & $27.83^{\mathrm{b}}$ & $30.83^{\mathrm{a}}$ & $28.83^{b}$ & 0.342 & 0.0001 \\
\hline
\end{tabular}

a,b and c : Means within each row with different superscripts are significantly differ $(\mathbf{P}<0.05)$. 


\section{C- Body dimensions:}

The values for withers height (WH), body length (BL), heart girth (HG) and rump width (RW) for B, $\mathrm{BA} \times \mathrm{A}$ and $\mathrm{BT} \times \mathrm{T}$ crossbred bulls are presented in Table 4. The $B A \times A$ had significantly higher values of $\mathrm{WH}$, $\mathrm{BL}, \mathrm{HG}$ and RW as compared with $\mathrm{B}$ genotype, either at puberty or sexual maturity. The BT $\times \mathrm{T}$ showed some superiority in $\mathrm{BL}$, either as compared with $\mathrm{BA} \times \mathrm{A}$ at sexual maturity or with $\mathrm{B}$ bulls in BL, $\mathrm{HG}$ and $\mathrm{WH}$ at puberty or sexual maturity. El-Barbary et al. (1995) and Ibrahim et al. (2005) indicated that all body measurements (except body length) were affected by age and genetic type, in such way, rump width was greater in Friesian pure breed than in $\mathrm{F} \times \mathrm{B}$. Also, Essi et al. (1987) reported that grading-up B with the HolsteinFriesian (HF) breed would result in an increase in body measurements.

Table 4: Body dimensions (cm) at puberty and sexual maturity of Baladi bulls and their crossbreds with Abondance and Tarentaise.

\begin{tabular}{|c|c|c|c|c|c|}
\hline \multirow{2}{*}{ Traits } & \multicolumn{3}{|c|}{ Genotype } & \multirow{2}{*}{$\pm \mathrm{SE}$} & \multirow{2}{*}{ P. value } \\
\hline & B & $\mathbf{B A} \times \mathbf{A}$ & $\mathbf{B T} \times \mathbf{T}$ & & \\
\hline & \multicolumn{4}{|c|}{ At puberty } & \\
\hline Withers height (WH) & $126.00^{b}$ & $128.17^{\mathrm{a}}$ & $127.33^{\mathrm{ab}}$ & 0.616 & 0.0423 \\
\hline Body length $(\mathrm{BL})$ & $122.33^{\mathrm{c}}$ & $139.83^{\mathrm{a}}$ & $130.17^{b}$ & 0.983 & 0.0001 \\
\hline Heart girth $\quad(\mathrm{HG})$ & $125.33^{b}$ & $135.50^{\mathrm{a}}$ & $136.17^{\mathrm{a}}$ & 1.357 & 0.0001 \\
\hline \multirow[t]{2}{*}{ Rump width $(\mathrm{RW})$} & $30.00^{\mathrm{b}}$ & $33.50^{\mathrm{a}}$ & $32.17^{\mathrm{a}}$ & 0.635 & 0.0049 \\
\hline & \multicolumn{4}{|c|}{ At sexual maturity } & \\
\hline Withers height (WH) & $138.50^{b}$ & $146.17^{\mathrm{a}}$ & $147.17^{\mathrm{a}}$ & 1.877 & 0.0099 \\
\hline Body length (BL) & $146.00^{c}$ & $159.33^{b}$ & $171.83^{\mathrm{a}}$ & 1.868 & 0.0001 \\
\hline Heart girth $\quad(\mathrm{HG})$ & $174.17^{b}$ & $182.67^{\mathrm{a}}$ & $183.50^{\mathrm{a}}$ & 1.373 & 0.0004 \\
\hline Rump width $(\mathrm{RW})$ & $38.00^{\mathrm{b}}$ & $43.67^{\mathrm{a}}$ & $44.50^{\mathrm{a}}$ & 1.159 & 0.0023 \\
\hline
\end{tabular}

a,b and c: Means within each row with different superscripts are significantly differ $(\mathbf{P}<0.05)$.

\section{D- Reproductive performance:}

1- Age, weight and testes circumference during different sexual periods:

Age, weight and testes circumference at puberty, sexual maturity and at slaughter (60 days post sexual maturity) are presented in Table 5. Crossbreeds (BT $\times$ T and $\mathrm{BA} \times \mathrm{A}$ ) reached age of puberty, sexual maturity and slaughter time earlier than Baladi bulls. Body weight and testes circumference were observed starting at puberty and continued to-more pronounced and significant at sexual maturity and slaughter time.

Results in Table 5 showed significant differences $(\mathrm{P}<0.0001)$ in age, body weight and testes circumference at puberty, sexual maturity and slaughtering among three genotypes. These significant positive differences were reflected in an increase of serum testosterone levels (Table 2). The present result indicated that hastened age of puberty and sexual maturity was related to heavier body weight and larger testicular size. These traits are related to each other. Ahmed et al. (1984) reported that there was pre-pubertal increase in testicular growth rate in Buffalo bulls but at considerably later stage of development (15-25 months) based on measurement of scrotal circumference as an index of testicular size. An increase in testicular weight during later part of pre-pubertal development has also been described in Holstein bulls (Curtis and Amann, 1981) and has been related to corresponding peak in levels of growth hormone (Joakimsen and Blom, 1976) and increased testosterone levels (Sundby and Velle, 1980). AbdEl-Hakeam et al. (1998) reported highly significant positive correlation coefficients among body weight, testes circumference and testosterone levels in both Buffalo and Friesian bulls.

Table (5): Age, body weight and testes circumference at puberty, sexual maturity and slaughter time of Baladi bulls and their crossbreds with Abondance and Tarentaise.

\begin{tabular}{|c|c|c|c|c|c|}
\hline \multirow{2}{*}{ Items } & \multicolumn{3}{|c|}{ Genotype } & \multirow{2}{*}{$\pm \mathbf{S E}$} & \multirow{2}{*}{ P. value } \\
\hline & B. & $\mathbf{B A} \times \mathbf{A}$ & $\mathbf{B T} \times \mathbf{T}$ & & \\
\hline \multicolumn{6}{|l|}{ Puberty: } \\
\hline Age (day) & $396.00^{\mathrm{a}}$ & $364.50^{b}$ & $339.33^{\mathrm{c}}$ & 3.219 & 0.0001 \\
\hline Body weight $(\mathrm{kg})$ & $244.33^{\mathrm{c}}$ & $255.67^{\mathrm{b}}$ & $263.67^{\mathrm{a}}$ & 1.342 & 0.0001 \\
\hline Testes circumference $(\mathrm{cm})$ & $23.67^{\mathrm{c}}$ & $24.17^{\mathrm{b}}$ & $25.83^{\mathrm{a}}$ & 0.149 & 0.0001 \\
\hline \multicolumn{6}{|l|}{ Sexual maturity: } \\
\hline Age (day) & $607.83^{\mathrm{a}}$ & $561.00^{\mathrm{b}}$ & $525.83^{\mathrm{c}}$ & 3.620 & 0.0001 \\
\hline Body weight $(\mathrm{kg})$ & $402.00^{c}$ & $414.67^{b}$ & $443.33^{\mathrm{a}}$ & 3.655 & 0.0001 \\
\hline Testes circumference $(\mathrm{cm})$ & $30.17^{\mathrm{c}}$ & $32.83^{b}$ & $34.00^{\mathrm{a}}$ & 0.310 & 0.0001 \\
\hline \multicolumn{6}{|l|}{ Slaughter: } \\
\hline Age (day) & $667.83^{\mathrm{a}}$ & $621.00^{b}$ & $585.83^{\mathrm{c}}$ & 3.620 & 0.0001 \\
\hline Body weight $(\mathrm{kg})$ & $424.67^{\mathrm{c}}$ & $437.33^{b}$ & $459.50^{\mathrm{a}}$ & 3.685 & 0.0001 \\
\hline Testes circumference $(\mathrm{cm})$ & $33.17^{b}$ & $35.58^{\mathrm{a}}$ & $36.00^{\mathrm{a}}$ & 0.248 & 0.0001 \\
\hline
\end{tabular}

a, band c : Means within each row with different superscripts are significantly differ $(\mathbf{P}<0.05)$. 


\section{2-Semen characteristics:}

Some physical properties, especially ejaculate volume, $\mathrm{pH}$, sperm motility, sperm concentration, motile sperm and abnormal sperm at puberty and sexual maturity are shown in Table 6. The differences in volume $(\mathrm{ml})$ of semen among the three genotypes were highly significant $(\mathrm{P}<0.0001)$. The ejaculate mean values were $1.12,1.37$ and $1.82 \mathrm{ml}$ at puberty and 1.82 , 2.27 and $2.92 \mathrm{ml}$ at sexual maturity for $\mathrm{B}$ and their crossbreeds BA $\times$ A and BT $\times$ T, respectively.

Volume of semen varies from one breed to another (Raja and Rao, 1982; Ahmed et al., 1993 and Hossain et al., 2012) and influenced by a number of factors such as age, breed, weight and season. Laing et al. (1988) reported that high fertility bull produced greater semen volume than that low fertility bull. Thus, ejaculate volume may be a good indicator of fertility.

Sperm cells concentrations of $\mathrm{BT} \times \mathrm{T}$ were significantly higher $(\mathrm{P}<0.0001)$ compared with $\mathrm{BA} \times \mathrm{A}$ and $\mathrm{B}$. The highest concentration of sperm $\left(424.17 \times 10^{6}\right.$ and $1.64 \times 10^{9} / \mathrm{ml}$ ) was obtained from $\mathrm{BT} \times \mathrm{T}$ and the lowest $\left(318.50 \times 10^{6}\right.$ and $\left.1.05 \times 10^{9} / \mathrm{ml}\right)$ from Baladi bulls at puberty and sexual maturity, respectively. The number of viable spermatozoa deposited in the female reproductive tract influences the fertilizing ability of the cow up to an upper level (Schenk et al., 1987 and Gerard and Humblot, 1991). Sperm concentration in the ejaculate is one of the important criteria of semen characteristics to qualify fertile males for breeding purposes (Graffer et al., 1988). These results are in agreement with Graffer et al. (1988) and Shelke and
Dhami (2001), they reported that significant differences in sperm concentration had been shown in semen from different bulls. A positive correlation between sperm concentration and motility had been reported (Everett $e t$ al., 1978 and Mathevonet al., 1998) which relies on over estimation of motility in more concentrated samples (Everett et al., 1978).

Generally, it was observed from Table 6 that most physical semen characteristics at puberty and sexual maturity of $\mathrm{BT} \times \mathrm{T}$ crossbreed bulls were significantly higher $(\mathrm{P}<0.0001)$ followed by $\mathrm{BA} \times \mathrm{A}$ compared to $\mathrm{B}$ bulls. This improvement of semen characteristics could be related to increasing of body weight, testes size and weight, in which they had higher values for $\mathrm{BT} \times \mathrm{T}$ crossbreed than Baladi bulls. Also, testosterone had higher values in $\mathrm{BT} \times \mathrm{T}$ and $\mathrm{BA} \times \mathrm{A}$ than B bulls (Table 2). Testosterone plays the major role in the development of reproductive organs and their functions (Hafez, 1987). Yassen and Mohamed (1972) found that there was a positive relationship between body weight and testicular size and their production of semen. During puberty, the androgenic effects resulting from increased testicular steroidogenesis are manifested by growth of the testes, external genitalia and the male accessory reproductive glands (prostate, seminal vesicles and bulbourethral), and beginning of secretory activity. Furthermore, the secondary sexual characteristics manifested during puberty can be divided into those that are a result of androgenic and anabolic effects (Kicman, 2008).

Table 6: Some physical semen characteristics at puberty and sexual maturity of Baladi bulls and their crossbreds with Abondance and Tarentaise.

\begin{tabular}{|c|c|c|c|c|c|}
\hline \multirow{2}{*}{ Semen characteristics } & \multicolumn{3}{|c|}{ Genotype } & \multirow{2}{*}{$\pm \mathrm{SE}$} & \multirow{2}{*}{ P. value } \\
\hline & B. & $\mathbf{B A} \times \mathbf{A}$ & $\mathbf{B T} \times \mathbf{T}$ & & \\
\hline & \multicolumn{4}{|c|}{ At puberty } & \\
\hline Seminal volume (ml) & $1.12^{\mathrm{c}}$ & $1.37^{\mathrm{b}}$ & $1.82^{\mathrm{a}}$ & 0.080 & 0.0001 \\
\hline Motility (\%) & $23.50^{\mathrm{c}}$ & $29.17^{b}$ & $35.83^{\mathrm{a}}$ & 1.363 & 0.0001 \\
\hline Semen $\mathrm{pH}$ & $7.05^{\mathrm{a}}$ & $6.95^{\mathrm{a}}$ & $6.92^{\mathrm{a}}$ & 0.074 & 0.439 \\
\hline Sperm concentration/ml $\left(\times 10^{6}\right)$ & $318.50^{\mathrm{c}}$ & $391.00^{\mathrm{b}}$ & $424.17^{\mathrm{a}}$ & 9.180 & 0.0001 \\
\hline Sperm output/ejac. $\left(\times 10^{6}\right)$ & $357.18^{\mathrm{c}}$ & $549.23^{\mathrm{b}}$ & $771.52^{\mathrm{a}}$ & 36.451 & 0.0001 \\
\hline Motile sperm/ml $\left(\times 10^{6}\right)$ & $74.71^{\mathrm{c}}$ & $114.11^{\mathrm{b}}$ & $152.83^{\mathrm{a}}$ & 6.991 & 0.0001 \\
\hline Motile sperm/ejac. $\left(\times 10^{6}\right)$ & $82.83^{\mathrm{c}}$ & $160.00^{b}$ & $277.41^{\mathrm{a}}$ & 14.998 & 0.0001 \\
\hline \multirow[t]{2}{*}{ Abnormal sperm (\%) } & $47.83^{\mathrm{a}}$ & $42.33^{\mathrm{b}}$ & $39.00^{\mathrm{b}}$ & 1.430 & 0.002 \\
\hline & \multicolumn{4}{|c|}{ At sexual maturity } & \\
\hline Seminal volume $(\mathrm{ml})$ & $1.82^{\mathrm{C}}$ & $2.27^{\mathrm{b}}$ & $2.92^{\mathrm{a}}$ & 0.080 & 0.0001 \\
\hline Motility (\%) & $72.67^{b}$ & $78.17^{\mathrm{a}}$ & $82.33^{\mathrm{a}}$ & 1.547 & 0.001 \\
\hline Semen $\mathrm{pH}$ & $7.07^{\mathrm{a}}$ & $6.91^{\mathrm{b}}$ & $6.93^{\mathrm{b}}$ & 0.029 & 0.003 \\
\hline Sperm concentration/ml $\left(\times 10^{9}\right)$ & $1.05^{\mathrm{c}}$ & $1.28^{\mathrm{b}}$ & $1.64^{\mathrm{a}}$ & 0.023 & 0.0001 \\
\hline Sperm output/ejac. $\left(\times 10^{6}\right)$ & $1.91^{\mathrm{c}}$ & $2.92^{\mathrm{b}}$ & $4.78^{\mathrm{a}}$ & 0.136 & 0.0001 \\
\hline Motile sperm/ml $\left(\times 10^{6}\right)$ & $76.41^{\mathrm{c}}$ & $100.30^{\mathrm{b}}$ & $134.82^{\mathrm{a}}$ & 3.039 & 0.0001 \\
\hline Motile sperm/ejac. $\left(\times 10^{6}\right)$ & $138.23^{\mathrm{c}}$ & $228.20^{\mathrm{b}}$ & $393.55^{\mathrm{a}}$ & 12.474 & 0.0001 \\
\hline Abnormal sperm (\%) & $21.00^{\mathrm{a}}$ & $17.33^{\mathrm{ab}}$ & $15.00^{\mathrm{b}}$ & 1.271 & 0.01 \\
\hline
\end{tabular}

${ }_{a, b}$ and ${ }^{\circ}$ : Means within each row with different superscripts are significantly differ $(\mathbf{P}<0.05)$.

\section{3- Reproductive organs and epididymal sperm reserves:}

French crossbreed $(\mathrm{BT} \times \mathrm{T}$ and $\mathrm{BA} \times \mathrm{A})$ bulls had the highest values $(\mathrm{P}<0.01)$ for all of reproductive organs compared with Baladi bulls. The results obtained in Table 7 indicated significant $(\mathrm{P}<0.01)$ genotype variations of the testes parameters with $\mathrm{BT} \times \mathrm{T}$ bulls had the highest values in all parameters, followed by $\mathrm{BA} \times \mathrm{A}$ and $\mathrm{B}$. Testes weights and testes mass index were 433.41, 377.23, $325.39 \mathrm{~g}$ and 0.95, 0.86, 0.77 in BT $\times \mathrm{T}$, 
$\mathrm{BA} \times \mathrm{A}$ and $\mathrm{B}$, respectively. $\mathrm{BT} \times \mathrm{T}$ bulls had higher values $(\mathrm{P}<0.05)$ of testes mass index than both $\mathrm{BA} \times \mathrm{A}$ and B. Moreover, total epididymis weight and accessory sex glands were much obvious in BT $\times \mathrm{T}$ bulls, in which the percent increase was $21.15 \%$ and $23.91 \%$, respectively. However, vas deferens weight was not significant different among the three genotypes, but still $\mathrm{BT} \times \mathrm{T}$ bulls had the highest values than others.

These results are in agreement with Addass et al. (2013) who reported that significant $(\mathrm{P}<0.001)$ genotype variability were observed for all testes parameters. The significant $(\mathrm{P}<0.05)$ breed difference on paired testicular measurements of bulls in this study was in agreement with many authors (Hamilton and Stark, 2000; Perry and Petterson, 2011 and Addass et al., 2013), they found that scrotal and epididymal traits in bulls are closely related to body weight and other measurement.
It has been established that maturation of spermatozoa occurs during the transit time through the epididymis and that the environment surrounds the spermatozoa in the cauda provides factors that enhance fertilizing ability. Therefore, spermatozoa from cauda epididymis give higher fertility than those from the caput and corpus epididymis (Hunter et al., 1976 and Hafez, 1987). Epididymis and vas deferens growth depends upon steroids of testicular origin, especially testosterone, and then testosterone should be high enough to support the growth (Wildeus et al., 1990 and Clark et al., 1996).

Testosterone concentration (Table 2) may be important for epididymal growth as well as vas deferens and other parts of the male genital tract. This hormone could diffuse through the tunica albugenia and influence the epididymis and subsequently vas deferens and other male genital tract organs (Abdel-Raouf, 1960).

Table 7: Reproductive organ weight (g) and length $(\mathrm{cm})$ of Baladi bulls and their crossbreds with Abondance and Tarentaise at slaughter (60 days post maturity).

\begin{tabular}{|l|c|c|c|c|c|}
\hline \multirow{2}{*}{ Traits } & \multicolumn{2}{|c|}{ Genotype } & \multirow{2}{*}{ \pm SE } & \multirow{2}{*}{ P. value } \\
\cline { 2 - 5 } & $\mathbf{B}$ & $\mathbf{B A} \times \mathbf{A}$ & $\mathbf{B T} \times \mathbf{T}$ & & \\
\hline Body weight at slaughter, Kg & $424.67^{\mathrm{b}}$ & $437.33^{\mathrm{b}}$ & $458.67^{\mathrm{a}}$ & 5.981 & 0.0189 \\
\hline Testes weight & $325.39^{\mathrm{c}}$ & $377.23^{\mathrm{b}}$ & $433.41^{\mathrm{a}}$ & 11.888 & 0.002 \\
\hline Testes mass index* & $0.766^{\mathrm{b}}$ & $0.863^{\mathrm{ab}}$ & $0.945^{\mathrm{a}}$ & 0.030 & 0.0165 \\
\hline Epididymis weight & $57.74^{\mathrm{c}}$ & $62.50^{\mathrm{b}}$ & $69.95^{\mathrm{a}}$ & 0.874 & 0.0002 \\
\hline Cauda weight & $22.35^{\mathrm{c}}$ & $24.07^{\mathrm{b}}$ & $26.20^{\mathrm{a}}$ & 0.302 & 0.0003 \\
\hline Corpus weight & $8.61^{\mathrm{c}}$ & $10.03^{\mathrm{b}}$ & $12.13^{\mathrm{a}}$ & 0.323 & 0.0007 \\
\hline Coput weight & $26.78^{\mathrm{c}}$ & $28.40^{\mathrm{b}}$ & $31.62^{\mathrm{a}}$ & 0.454 & 0.0008 \\
\hline Accessory sex glands weight & $49.22^{\mathrm{c}}$ & $54.95^{\mathrm{b}}$ & $60.99^{\mathrm{a}}$ & 0.674 & 0.0001 \\
\hline Cowper weight & $11.48^{\mathrm{c}}$ & $12.86^{\mathrm{b}}$ & $14.36^{\mathrm{a}}$ & 0.277 & 0.001 \\
\hline Ampulla weight & $16.56^{\mathrm{c}}$ & $18.89^{\mathrm{b}}$ & $20.44^{\mathrm{a}}$ & 0.412 & 0.001 \\
\hline Seminal vesicle & $21.18^{\mathrm{c}}$ & $23.21^{\mathrm{b}}$ & $26.19^{\mathrm{a}}$ & 0.324 & 0.0001 \\
\hline Vas deferens weight & 8.83 & 9.68 & 9.88 & 0.329 & 0.133 \\
\hline Penis weight & $302.70^{\mathrm{b}}$ & $387.34^{\mathrm{a}}$ & $433.48^{\mathrm{a}}$ & 13.912 & 0.001 \\
\hline Penis length & $82.25^{\mathrm{b}}$ & $85.48^{\mathrm{a}}$ & $87.41^{\mathrm{a}}$ & 0.795 & 0.01 \\
\hline
\end{tabular}

a,b and $\mathrm{c}$ : Means within each row with different superscripts are significantly differ $(\mathbf{P}<0.05)$.

*Testes mass index $=$ testes weight $(\mathrm{g}) /$ body weight $(\mathrm{kg})$.

Meanwhile, significant genotypes effect on sperm production among $\mathrm{BT} \times \mathrm{T}, \mathrm{BA} \times \mathrm{A}$ and $\mathrm{B}$ bulls was evident where $\mathrm{BT} \times \mathrm{T}$ had the highest values in all parameters. Total epididymal sperm reserve (Table 8) was significantly high $(\mathrm{P}<0.001)$ and increased in $\mathrm{BT} \times \mathrm{T}$ $\left(13.78 \times 10^{9}\right)$ followed by $\mathrm{BA} \times \mathrm{A}\left(10.85 \times 10^{9}\right)$ while $\mathrm{B}$ had the least values $\left(9.83 \times 10^{9}\right)$. This significant increase due to genotype effect might be related to the significant differences among the three genotypes in body weight, testes circumference and testes weight at sexual maturity and slaughter as mentioned above.

Meanwhile, it was found that cauda epididymal sperm reserve accounted for more than $60 \%$ of the total stored epididymal sperm reserve, while caput and corpus sperm reserve accounted for about $20 \%$ and $11 \%$ of total epididymal sperm reserve, respectively (Table, 8). These results are in agreement with Jindal and Panda (1980), AbdEl-Hakeam and El-Feel (1992) and AbdElHakeam (2000). The special ability of cauda epididymis to store sperm is dependent on low scrotal temperature and the action of male sex hormone (Foldsey and Bedford, 1982).

Sperm production per gram testicular tissue was also significantly higher in $\mathrm{BT} \times \mathrm{T}$ bulls than the two other genotypes. The results obtained on sperm reserve count in the present study are consistent with those findings of Tegegne et al. (1992b); Britto et al. (2002 \& 2006) and Addass et al. (2013), they reported breed variability in gonadal and extra gonadal sperm reserve in Bosindicus genetic group. Gonadal sperm production has been reported to be dependent on the amount of sperm produced by testicular parenchyma tissue which is mainly influenced by nutrition and breed (Tegegne et al., 1992a and b). Increased sperm production had reported to be associated with fat cover and scrotal surface temperature (Britto et al., 2002). Positive correlation was also reported between sperm production and scrotal testicle shape (Stephen, 2002) and body condition score (Ikhatua and Olayiwole, 1982). 
Table 8: Epididymal sperm reserves of Baladi bulls and their crossbreds with Abondance and Tarentaise at slaughter time $(60$ days post maturity.

\begin{tabular}{|c|c|c|c|c|c|}
\hline \multirow{2}{*}{ Semen characteristics } & \multicolumn{3}{|c|}{ Genotype } & \multirow{2}{*}{$\pm \mathrm{SE}$} & \multirow{2}{*}{ P. value } \\
\hline & B. & $\mathbf{B A} \times \mathbf{A}$ & BT $\times \mathbf{T}$ & & \\
\hline Total Epididymal sperm reserves $\left(\mathrm{x} 10^{9}\right)$ & $9.83^{\mathrm{c}}$ & $10.85^{b}$ & $13.78^{\mathrm{a}}$ & 0.229 & 0.0001 \\
\hline Cauda sperm $\left(\mathrm{x} 10^{9}\right)$ & $6.73^{b}$ & $7.03^{\mathrm{b}}$ & $8.90^{\mathrm{a}}$ & 0.166 & 0.0002 \\
\hline Corpus sperm $\left(\times 10^{9}\right)$ & $1.10^{\mathrm{b}}$ & $1.45^{\mathrm{b}}$ & $1.93^{\mathrm{a}}$ & 0.121 & 0.01 \\
\hline Caput sperm $\left(\times 10^{9}\right)$ & $1.99^{\mathrm{c}}$ & $2.37^{\mathrm{b}}$ & $2.95^{\mathrm{a}}$ & 0.026 & 0.0001 \\
\hline Sperm cell /g. testicular tissue $\left(\times 10^{9}\right)$ & $24.97^{\mathrm{b}}$ & $27.11^{b}$ & $31.08^{\mathrm{a}}$ & 0.777 & 0.004 \\
\hline
\end{tabular}

a,b and c : Means within each row with different superscripts are significantly differ $(\mathbf{P}<0.05)$.

In conclusion, the superiority of crossbred bulls in growth, reproductive performance and feed efficiency especially with the second generation of Tarentaise breed with Baladi $(\mathrm{BT} \times \mathrm{T})$ compared with pure Baladi bulls was clear. This conclusion could be recommended to improve growth, reproductive performance and feed efficiency.

\section{REFERENCES}

Abd El-Hafeez, A. M.; Mohamed, M. Y.; Mahgoub, A. A. S.; Ahmed, M. A. M.; El-Banna, M. K. and Zahed, S. M. (2014).Evaluating the crossbreeding of Baladi cows and their crossbreds with French abondance and tarentaise breeds through studying the production potential, milk quality and its products. J. Egypt. Vet. Med. Asso., 174 (3): 493.

Abd El-Hafeez, A. M.; Mohamed, M. Y.; Mahgoub, A. A. S.; Zahed, S. M. and El-Banna, M. K. (2015). Immune status and growth performance of Baladi bulls and their crossbreds with abondance and tarentaiseunder middle Egypt conditions. J. Egypt. Vet. Med. Asso., 75 (3): 523.

AbdEl-Hakeam, A. A. (2000). Testicular function and reproductive tract development ofbuffalo and Friesian bulls as affected by hemicastration. Minia J. Agric. Res \& Dev., 20 (3): 477.

AbdEl-Hakeam, A. A. and El-Feel, F. M. R. (1992). Effect ofhemicastration and genotype on growth, reproductive tract development and epididymal sperm reserves in male goats.Minia J. Agri. Res. \& Dev., 14: 1023.

AbdEl-Hakeam, A. A.; Abd El-Moty, A. K. I.; El-Feel, F. M. R. and Abu-Elawa, M. (1998). Reproductive performance of buffalo and Friesian calves as affected by flavomycin growth promoter. Egypt. J. Anim. Prod., 35(1): 55.

AbdEl-Hakeam, A.A.; Rabie, Z. B. H. and Hassan, H. A. (1994).Weight of reproductive organs and epididymal sperm reserves of ram lambs as affected by genotype, feeding level and age.Minia J. Agric. Res \& Dev., 16 (2) 553.

AbdEl-Hakeam, A. A.;Yassin, A.M.; El-Alamy, M. A. and Tony, S. M. (1978). Sperm output potential of Ossimi rams. Alex. Agric. Res., 26: 557.
Abd El-Moty, A. K. I.; AbdEl-Hakeam, A. A.; ElBarody, M. A. A.; El-Feel, F. M. R. and Baiomy, A. A. (2001). Reproductive response of buffalo and Friesian male bulls subjected to sexual biostimulant. Egyptian Soc. Anim. Reprod.Fert. Thirteenth Annual Cong. Giza, 22-26: 159.

Abdel-Raouf, M. (1960).The postnatal development of the reproductive organs in the bulls with special reference to puberty.Acta Endocrinologica, 34 (suppl. 49): 1 .

Addass, P. A.; Midau, A.; Yahya, M. M. and Tizhe, M. A. (2013). Genotype variation, age and body condition score on some paired testes measurements among common indigenous bull cattle breeds in Mubi. Annals of Biological Research, 4 (8):253.

Ahmed, J. U.; Shamsuddin, M. andAlam, M. G. S. (1993). Breeding soundness of the bull used for artificial insemination in Bangladesh. Bang. J. Agric. Sci., 20: 225.

Ahmed, M.; Latif, M.; Ahmed, M.; Qazi, M. M. H.; Sahir, N. and Arslan, M. (1984). Age related changes in body weight, scrotal size and plasma testosterone levels in buffalo. Ed. W. Ross Cockrill. F. A. O. Rome, pp 105-158.

Amann, R. P. (1981). A critical review of methods for evaluation of spermatogenesis from seminal characteristics.Journal of Andiology, 2: 37.

Ashmawy, N. A.; El-Gaafarawy, A. M.; Ibrahim, S. A. and Ali, M. A. E. (2002). Physiological responses and blood biochemical changes in Egyptian Baladi and crossbred cattle under conditions of north of Nile Delta. J. Egypt.Vet.Med.Ass., 62 (6a): 125 .

Brito, L. F.; Silva, A. E.;Deragon, L. A. and Kastelic, J. P. (2002). Effect of age and genetic group on characteristics of the scrotum testes and testicular vascular cones and sperm production and semen quality in AI bulls. Thenogenology, 2002.

Brito, L. F.; Silva, A. E.; Rodrigues, L. H.;Viera, F. V.; Deragon, L. A and Kastelic, J. P. (2006). Effects of age and environmental factors on semen production and semen quality of Austrian Simmental bulls.Animal Reproduction Science, 2006.

Clark, A. M.; Samaras, S. E.; Hammond, J. M.; Bryan, K. A. and Hagen, D. R. (1996). Hemicastration of neonatal boars: hormonal responses and testicular messenger RNA for insulin-like growth factor-1. Anim. Reprod. Sci., 41 (3-4): 279. 
Collier, R.; J. McNamara; C. Wallace and M. Dehff (1984). A review of endocrine regulation of metabolise during lactation, J. Anim. Sci., 59:498.

Curtis, S. K. and Amann, R. P. (1981).Testicular development and establishment of spermatogenesis in Holstein bulls. Biol. Reprod., 34: 71.

Dahman, J. J.; Jacobs, J. A. and Morrison, E. J. (1985). Suffolks versus Lincoln rams, the influence of sire and breed cross on carcass traits of heavy market lambs. J. Anim. Sci., 61: 98.

Duncan, D. B. (1955).Multiple ranges and multiple F. Test. Biometrics, 11: 1.

El-Barbary, A. S. A.; Mahdy, A. E. and Kassab, M. S. (1995). Body measurements and growth from birth to 18 months of age in Friesian bulls and their crossbreds. Alex. J. Agric. Res., 40:19.

Essi, A.; Haiger, A. and Steinwender, R. (1987). Comparison of Austrian Brown cattle with Brown Swiss and Holstein-Friesian crossbreeds. Part8.Estimation of crossbreeding parameters. Bodenkultur, 38: 351.

Everett, R. W.; Bean, B. and Foote, R. H. (1978).Sources of variation of semen output. J. Dairy Sci., 61: 90.

Foldsey, R. G. and Bedford, J. M. (1982). Biology of the scrotum. (1) Temperature and Androgen as determination of the sperm storage capacity of the rat cauda epididymis. Boil. Reprod., 26: 673.

Gerard, O. and Humblot, P. (1991). Influence of interactions between semen extender and number of spermatozoa on nonreturn estimates of fertility for individual Holstein bulls. Theriogenology.36: 727.

Graffer, T.; Solbu, H. and Filseth, O. (1988). Semen production in artificial insemination bulls in Norway. Theriogenology, 30: 1011.

Hafez, E. S. E. (1987). Reproduction in Farm Animals.Lea and Febiger, Phladelphia, U. S A.

Hamilton, T. and Stark, D. (2000). Beef bull fertility Ministry of Agriculture and food fact sheet. Queens printer for Ontario.Ag.info@omaf.gov.ca 2000: $1-7$.

Hansen, G. R. (2006). Managing bull fertility in beef cattle herds.AN153 series of animal Science Department, Florida.Cooperative extension service institute of food and AgriccuturalSciences. University of Florida (2006). EDIS website at http//edis.afas.ufl.edu.osterhoff (1990). In improving reproduction in farm animals . I.N. Wiltbank. Class notes. Animal Science 510, 1990. Brigham Young University.P: 382.

Hoogenboezem, J. and Swanepoel, F. (2000). Zootecnological aspect of bull fertility.Animal genetic Resource lowa. Stat university press.

Hossain, M. E.; Khatun, M. M.; Islam, M. M. and Miaz, O. F. (2012). Semen characteristics of breeding bulls at the Central Cattle Breeding and Dairy Farm of Bangladesh

Hunter, R. H. F.; Holtz, W. and Henfrey, O. J. (1976). Epididymal function in the boar in relation to the fertilizing power of spermatozoa. J. Reprod. Fert., 46: 463.
Ibrahim, S.; El-Gaafarawy, A. M.; El-Sheikh, S. M.; Hanaa, A. El-Koussy and Swiefy, S. A. (2005). Feeding and meat production-related parameters in Baladi, Abondancex Baladi and Tarentaise $\times$ Baladi fattened bulls. Proc. $2^{\text {nd }}$ Conf.Anim. Prod. Res. Inst., Sakha, 27-29. Sep.: 107.

Ikhatua, U. I. and Olayiwole, M. B. (1982). Seasonal effects on performance of feed lot bulls. Journal of Animal Production Research, 2 (2): 99.

Jaffe, B. M. and Behman, N. A. B. (1974). Methods of hormone radioimmunoassay.Academic Press.

Jindal, S. K. and Panda, J. M. (1980).Epididymal sperm reserves of the goat (Caprahircus). J. Reprod. Fert., 59: 469.

Joakinsen, D. and Blom, A. K. (1976). Growth hormone concentration in jugular blood plasma in relation to growth rate and age in young bulls.Acta Agri. Scand., 26: 239.

Kicman, A. T. (2008). Pharmacology of anabolic steroids.Br. J.Pharmacol., 154(3): 502.

Laing, J. A.; Morgan, W. J. B. and Wagner W. C. (1988). Fertility and infertility in the domestic animal. 4thedn. Baillere, Tindall, London.

Lapierre, H.; Petitclerc, D.; Pelletier, G.; Delorme, L.; Dubreuil, P.; Morisset, J.; Gaudreau, P.; Couture, Y. and Brazeau, P. (1990). Effect of growth hormone releasing factor and (or) thyrotropin releasing hormone factor on hormone concentration and milk production in dairy cows. Can. J. Anim. Sci., 70:175.

Mathevon M.; Buhr M. M. and Dekkers, J. C. M. (1998). Environmental, management and genetic factors affecting semen production in Holstein bulls. J. Dairy Sci., 81: 3321.

Mokhless, E. M. and Ibrahim, S. A. (1990). Postnatal development of the male genital system of growing Egyptian buffalo calves with special reference to testosterone concentration in blood plasma. Annales of Agri. Sci., Moshtohor, 28: 2025.

Murray, P. J.; Rowe, J. B.; Pethick, D. W. and Adams, N. R. (1990). The effect of nutrition on testicular growth in the Merino rams. A. B. A., 59: 140.

NRC (1988). Nutrient Requirements of Dairy Cattle ( $6^{\text {th }}$ Ed.).National Academy Press, Washington, DC.

Nworgu, F. C.; Ogungbenro, S. A. and Solesi, K. S. (2007). Performance and some blood chemistry indices of broiler chicken served fluted pumpkin (Telfariaaccidentalis) leaves extract supplement. Am. Eurasian J. Agric. Environ. Sci., 2 (1): 90.

Perry, G. and Petterson, D. (2011). Determining reproductive fertility in herd bulls. University of Misouri Agricultural Publication G.,pp: 1-8.

Raja, M. S. and Rao, A. R. (1982). Note the semen characteristics of crossbred and purebred bulls. Ind. J. Anim. Sci., 52: 230.

Sajjad, M.; Ali, S.; Uallah, N.; Anwar, M.; Akhter, S. and Andrabi, S. M. H. (2007). Blood serum testosterone level and its relationship with scrotal circumference and semen characteristics in NiliRavi buffalo bulls. Pakistan Vet. J., 27 (2):63. 
SAS (2002). User's Guide: Statistics, Version 9.0 Edition. SAS Institute Inc., Cary, NC, USA.

Schenk, J. L.; Amann, R.P. and Allen, C. H. (1987). Effects of extender and insemination dose on postthaw quality and fertility of bovine sperm. J. Dairy Sci., 70: 1458.

Shelke, V. B. and Dhami, A. J. (2001). Comparative evaluation of physico-morphological attributes and freezability of semen of Gir cattle (Bosindicus) and Jafarabadi buffalo (Bubalusbubalis) bulls. Ind. J. Anim. Sci., 71: 319.

Stephen, B. B. (2002). Age at puberty and scrotal circumference are important factors to bull selection.Webmaster@cattletoday.com.

Sundby, A. and Velle, W. (1980).Plasma concentration of testosterone in young bulls in relation to age, rate of weight gain and stimulation with HCG. J. Endocrinology, 86: 465.
Tegegne, A.; Enstwistle, K. W. and Mukasa-Mugarwa, E. (1992a). Gonodal and extragonodal sperm reserves and testicular histometrics characteristics in zebu and cross breed bulls. Effect of dry season nutritional supplementation. Animal reproduction science, 29: (1-2): 25.

Tegegne, A.; Enstwistle, K. W. and Mukasa-Mugarwa, E. (1992b). Gonodal and extragonodal sperm reserves in small east African Zebu (Bosindicus) bulls in Ethiopia. Tropical Animal Health production, 24(4): 216.

Wildeus, S.; Randel, R. D.; Guthrie, M. J. and Drawer, E. (1990). Testicular characteristics, LH and testosterone and onset of puberty in Bosindicus $\mathrm{x}$ Bos Taurus crossbred bulls following hemicastration at three stages pre-puberty. Int. J. Anim. Sci., 5(1): 33.

Yassen, A. M. and Mahmoud, M. N. (1972). Relation between body weight and testicular size in buffalo bulls. J. Agri. Sci. Camb., 78: 367.

\section{خصائص السائل المنوى،تطور القتاة التناسلية، الكفاءة الغذائية وبعض قياسـات اللام للطلائق البلديـة وخلطانها مـع

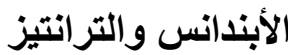

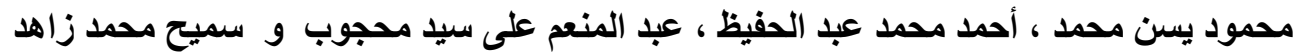

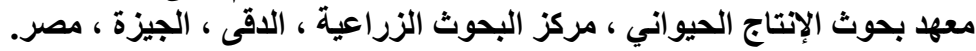

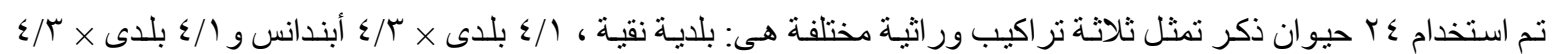

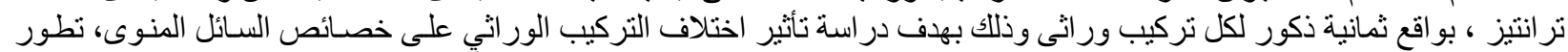

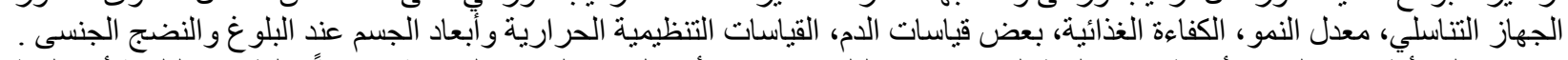

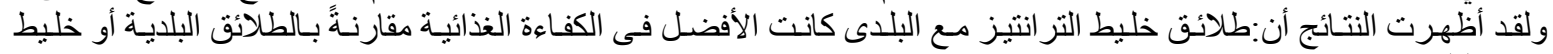

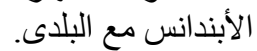



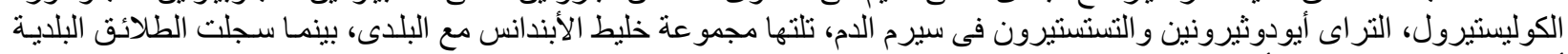

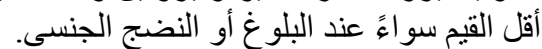

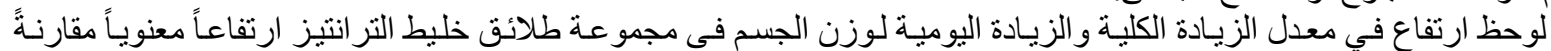
بمجمو عة خليط الأبندانس مع البلدى أو مجمو عادة الطلائق البلائية النقية.

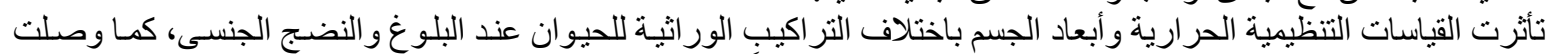

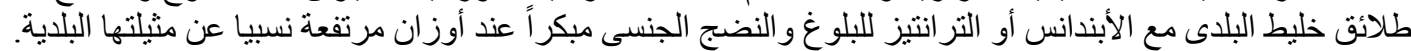

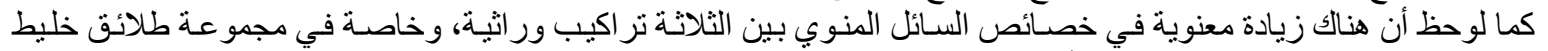

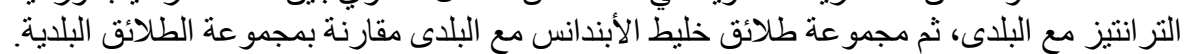

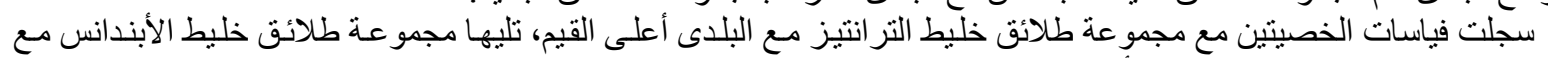
البلاى، بينما سجلت مجمو عة البلدى النقية أقل القيم.

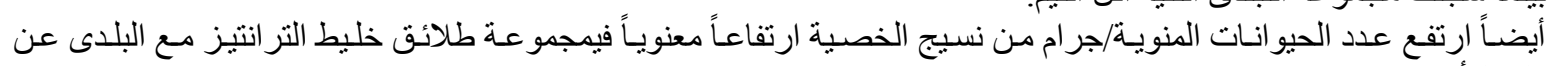

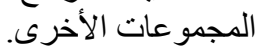

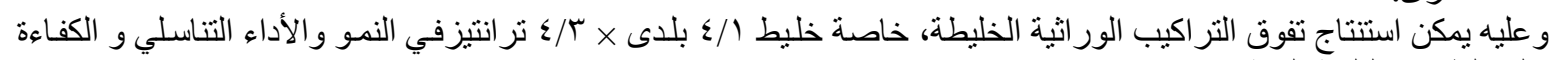
الغذائية على الطلائق البلدية النقية.
} 